\title{
Novel 2-(5-Imino-5H-isoquinolones[3,4-b]quinoxalin-7-ylmethyl)- benzonitrile (DIQ3) and Other Related Derivatives Targeting Colon Cancer Cells: Syntheses and in Vitro Models
}

\author{
Alissar Monzer, ${ }^{\dagger, \|}$ Nayri Jabotian, ${ }^{\ddagger}, \|$ Farah Ballout, ${ }^{\dagger}$ Jie S. Zhu, ${ }^{\S \odot}$ Mark J. Kurth, ${ }^{\S \odot(\odot) ~}$ \\ Makhluf J. Haddadin, ${ }^{*}$ and Hala Gali-Muhtasib* ${ }^{\dagger} \uparrow$ \\ ${ }^{\dagger}$ Department of Biology, and Center for Drug Discovery, and ${ }^{\ddagger}$ Department of Chemistry, American University of Beirut, Riad El \\ Solh, 11072020 Beirut, Lebanon \\ ${ }^{\S}$ Department of Chemistry, University of California at Davis, One Shields Avenue, Davis, California 95616-5295, United States
}

Supporting Information

ABSTRACT: Chemotherapy has been shown to be effective in reducing the progression and development of cancer in metastatic patients. However, drug selectivity is still a major issue for most chemotherapeutics. In this study, we synthesized four novel heterocyclic compounds having similarity in structure with quinone systems whereby nitrogen atoms replace the oxygen atoms. The anticancer activity of these compounds (DIQ3-6) was tested against HCT116 human colon cancer cells. We showed that all four heterocycles caused significant reduction in colon cancer cell viability at doses as low as $4 \mu \mathrm{M}$, a concentration that was not cytotoxic to normal human FHs74Int intestinal cell lines. Interestingly, these heterocycles inhibited colon sphere formation in $3 \mathrm{D}$ cultures at first generation $\left(\mathrm{G}_{1}\right)$, mainly because of inhibition of proliferation as evidenced by Ki67 staining. Thus, DIQ3 causes sufficient eradication of the self-renewal ability of the highly resistant cancer stem cells. This study represents the first documentation of the activity of these novel heterocyclic compounds, particularly compound DIQ3, and their potential therapeutic use in targeting colon cancer self-renewal capacity. Our findings provide the basis for proposing these nontoxic and stable compounds for additional testing against cancer.

\section{INTRODUCTION}

Over the past decades, ongoing research in the fields of chemotherapy, radiation therapy, surgery, and others have progressed noticeably. ${ }^{1,2}$ Despite improvements in all other fields, chemotherapy still plays an essential role in cancer treatment, knowing that $90 \%$ of cancer deaths are a result of metastasis. $^{3}$

Most of the drugs used in cancer chemotherapy are of natural origin, whether from plants, microorganisms, or even marine species. ${ }^{3}$ The active organic compounds that were extracted from these natural sources have often been replaced with synthetic ones. ${ }^{4}$ Recent studies have shown that some quinones, which are often plant-derived secondary metabolites, ${ }^{5}$ are active agents against cancer. ${ }^{6}$

Quinones possess a cyclic structure with two keto functional groups. ${ }^{7}$ In an aprotic medium, each keto group can be reduced in a one electron reduction step. The two successive steps produce semiquinone and quinonedianion $\left(\mathrm{Q}^{2-}\right)$, respectively. ${ }^{8}$ Some of the most well-known anticancer agents that belong to the quinone family are shown in Figure 1. It is important to mention the belief that the chemotherapeutic drugs adriamycin and mitomycin $\mathrm{C}$ act as anticancer active agents through the redox quinone-hydroquinone system. ${ }^{9,10}$ In addition, $p$-quinonimines such as the 1,2,4-benzotriazinones have shown anticancer activity. ${ }^{11,12}$

Although more than 200 drugs have been discovered with activity against different types of cancer, each however has its own side effects. ${ }^{13}$ The main drawbacks of chemotherapy include the presence of low and insufficient concentration of the drug at the tumor site, high toxicity, and drug resistance. ${ }^{1}$ In addition, the major problem with chemotherapy is its lack of selectivity, which leads to the death of both cancer and normal cells. $^{14}$

Targeted therapy emerged with the aim of destroying only cancerous cells, and currently, many drugs of this sort are FDA approved and are being used. Even though it might have overcome the selectivity issue in some cases, targeted therapy still causes some side effects. ${ }^{15}$

For several decades, chemotherapy drugs for metastatic cancers have shown partial benefit as only $50 \%$ of patients receiving therapy develop recurrence. ${ }^{16}$ Therapy failure is believed to occur because available chemotherapeutics shrink the tumor bulk by eliminating the chemo-sensitive clones but

Received: October 8, 2018

Accepted: January 9, 2019

Published: February 14, 2019 


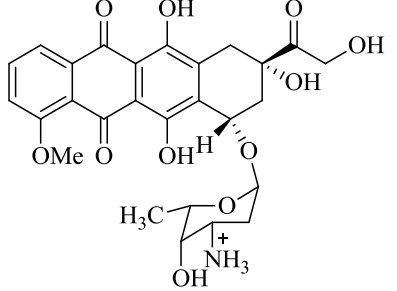

Doxorubicin (Adriamycin)<smiles>COC1(OC)C2C(C)=C(N)C(=O)C(COC(N)=O)=C2N2CNCC21</smiles>

Mitomycin C

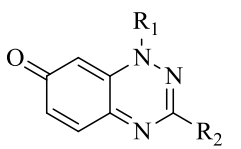

1,2,4-benzotriazinone

Figure 1. Structures of some anticancer quinones.

Scheme 1. Synthesis of the Different Analogues of DIQ3

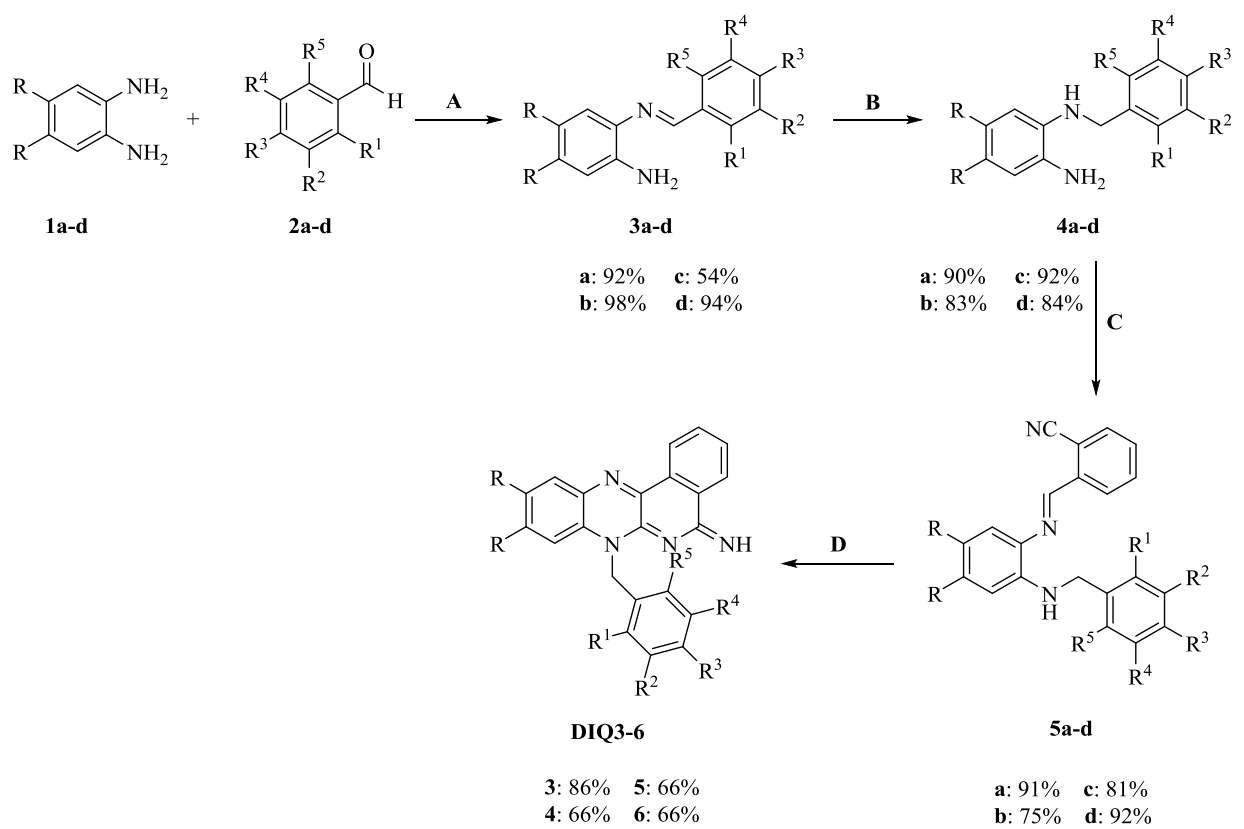

a,DIQ3: $\mathrm{R}=\mathrm{R}^{2}=\mathrm{R}^{3}=\mathrm{R}^{4}=\mathrm{R}^{5}=\mathrm{H}, \mathrm{R}^{1}=\mathrm{CN}$
b,DIQ4: $\mathrm{R}=\mathrm{R}^{1}=\mathrm{R}^{2}=\mathrm{R}^{4}=\mathrm{R}^{5}=\mathrm{H}, \mathrm{R}^{3}=\mathrm{CN}$
c,DIQ5: $\mathrm{R}=\mathrm{R}^{2}=\mathrm{R}^{5}=\mathrm{H}, \mathrm{R}^{1}=\mathrm{NO}_{2}, \mathrm{R}^{3}=\mathrm{R}^{4}=\mathrm{OCH}_{3}$
d,DIQ6: $\mathrm{R}=\mathrm{R}^{2}=\mathrm{R}^{3}=\mathrm{R}^{4}=\mathrm{R}^{5}=\mathrm{H}, \mathrm{R}^{1}=\mathrm{NO}_{2}$
(A) a: $\mathrm{EtOH}$, r.t.; b: $\mathrm{MeOH}$, r.t.; c: $\mathrm{MeOH}: \mathrm{CH}_{3} \mathrm{CN}$, r.t.; d: $\mathrm{MeOH}$, r.t. (B) a,b,d: $\mathrm{NaBH}_{4}, \mathrm{MeOH}$, r.t.; c: $\mathrm{MeOH}: \mathrm{CH}_{3} \mathrm{CN}$, r.t.

(C) O-cyanobenzaldehyde, DMSO, $\mathrm{CH}_{3} \mathrm{COOH}$ (cat. amount) r.t.; (D) 3: $\mathrm{KCN}, \mathrm{CH}_{3} \mathrm{CN}$, r.t.; 4,5,6: $\mathrm{KCN}, \mathrm{CH}_{3} \mathrm{CN}, 60-65^{\circ} \mathrm{C}$ do not eradicate chemo-resistant clones or cancer stem cells (CSCs), which replenish the tumor. Thus, the identification of a drug that simultaneously targets CSCs and chemo-resistant cells is of high importance for clinical treatment and for effective eradication of some types of cancer. CSCs express distinctive arrays of surface biomarkers, which make them vulnerable to therapies targeting multiple possible cellular pathways. ${ }^{16}$ In this study, we report the synthesis of four novel heterocyclic compounds (Scheme 1); four of which were investigated for anticancer activity against human colon cancer HCT116 cells.

\section{RESULTS AND DISCUSSION}

Compound DIQ3 and its analogues (DIQ4-6) were synthesized in four steps as illustrated in Scheme 1. All the intermediates $(\mathbf{3} \mathbf{a}-\mathbf{d}, \mathbf{4} \mathbf{a}-\mathbf{d}, \mathbf{5} \mathbf{a}-\mathbf{d})$ involved in these reactions were isolated and characterized as well.

All compounds 3-5 were prepared at room temperature because compounds $\mathbf{3}$ and $\mathbf{5}$ are unstable at high temperatures, yielding the corresponding benzimidazole derivative in the presence of oxygen. Also, in preparation of compounds 3 and
5, the usage of a minimum amount of solvent was very crucial to obtain high yields.

The preparation of imine 3 was accomplished through the mono condensation between $o$-phenylenediamine 1 ( 1 equiv) and aldehyde 2 (1.2 equiv) at room temperature. The formation of the imine $(\mathrm{HC}=\mathrm{N})$ bond can be easily observed in the ${ }^{1} \mathrm{H}$ NMR because of its diagnostic $\mathrm{CH}$ between 8 and 9 ppm. Compound 3 was then reduced with excess $\mathrm{NaBH}_{4}$ in methanol to afford 4. The indicative peaks for this reduction in the ${ }^{1} \mathrm{H}$ NMR are the disappearance of the singlet at 8-9 ppm for the $\mathrm{CH}=\mathrm{N}$ and the appearance of a doublet at 4-5 ppm for the $\mathrm{CH}_{2}$ and a broad peak at around $5 \mathrm{ppm}$ corresponding to the NH. Compound 4 ( 1 equiv) was further treated with 2cyanobenzaldehyde (1.2 equiv) in dimethyl sulfoxide (DMSO) in addition to a few drops of acetic acid at room temperature to afford compound $\mathbf{5}$. Upon treating orange compound $\mathbf{5}$ with an excess of $\mathrm{KCN}$ (previously dissolved in water) in acetonitrile between 60 and $65{ }^{\circ} \mathrm{C}$, compound DIQ precipitated out of solution as a yellow solid. In bulk, the yellow precipitates (DIQ3-6) have a minor yellow component which travels fast on thin-layer chromatography (TLC), which we believe results from hydrolysis of the imino group to the 
Scheme 2. Proposed Mechanism of the Cascade Cyclization
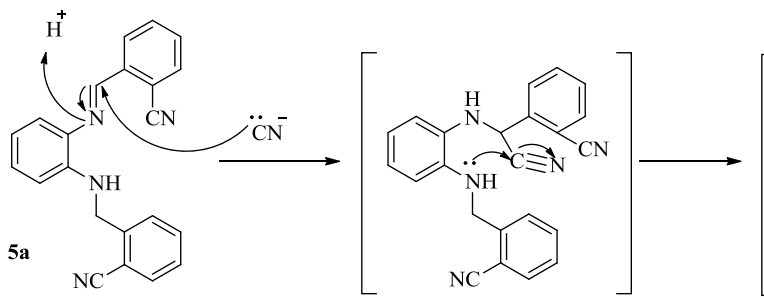<smiles>N#Cc1ccccc1CN1C(=N)C(c2ccccc2C#N)Nc2ccccc21</smiles>

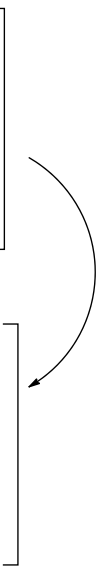

air<smiles>N#Cc1ccccc1CN1C2=Nc3c(c4nc5c6ccccc6c(=N)nc-5n(Cc5ccccc5C#N)c4c4ccccc34)C(N)=NC2=c2ccccc2=C1N</smiles>

Compound DIQ3

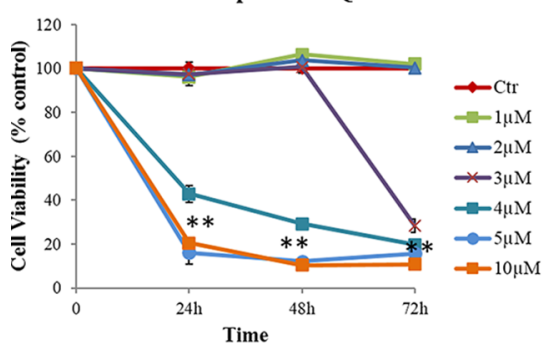

Compound DIQ5

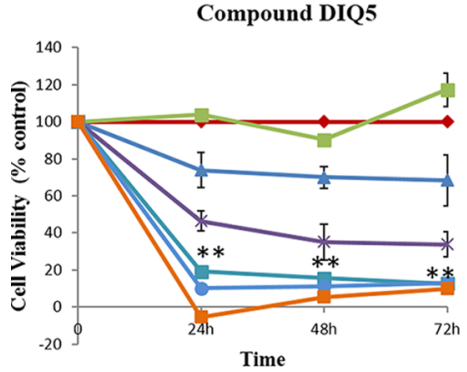

Compound DIQ4

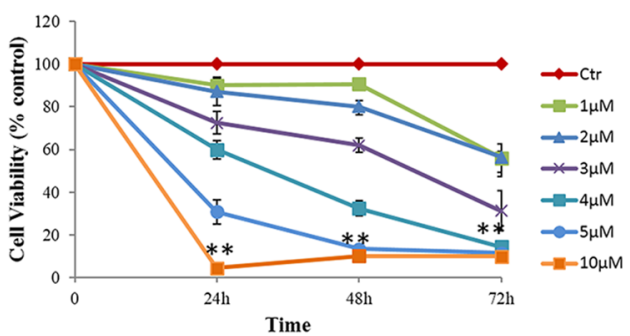

Compound DIQ6

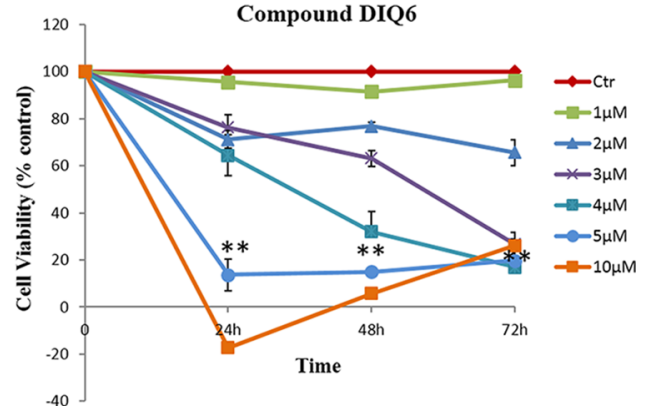

Figure 2. DIQ3 and related derivatives reduce the viability of HCT116 cell line as assessed by MTT. The antitumor effect of different concentrations of DIQ3 and its related derivatives (compounds DIQ4-6) on the viability of HCT116 cells was determined in sextuplicates at 24, 48 , and $72 \mathrm{~h}$ using MTT assay. Results are expressed as percent of control. The data are reported as mean of $n=2 \pm$ SEM $(* P<0.05$, **P<0.01 using Student's $t$-test).

hard to isolate keto form. The pure DIQ3-6 was obtained by leaching the yellow products with methanol to get rid of this minor yellow impurity. All derivatives of DIQ were brightly fluorescent, except for DIQ5, which allowed them to be easily visualized on TLC using long wavelength UV (365 nm). Furthermore, these compounds moved very slowly on TLC, even with ethyl acetate-methanol $(9: 1)$ as the mobile phase.

The addition of KCN followed by a cascade of reactions to afford the different analogs of DIQ might be explained by the proposed mechanism shown in Scheme 2.
The following mechanism was proposed based on similar cyanation reactions done by Haddadin et al. ${ }^{17}$

DIQ3 and Related Derivatives Reduce the Viability of Human Colon Cancer HCT116 Cell Line in 2D in Vitro Models at Doses That Are Not Cytotoxic to Normal FHs74Int Cells. To assess the antitumor effect of compound DIQ3 and its related derivatives (DIQ4-6) on human colon cancer HCT116 cell lines, we employed the MTT assay. The MTT results revealed that all drugs were capable of significantly inhibiting the metabolic activity of the colon 

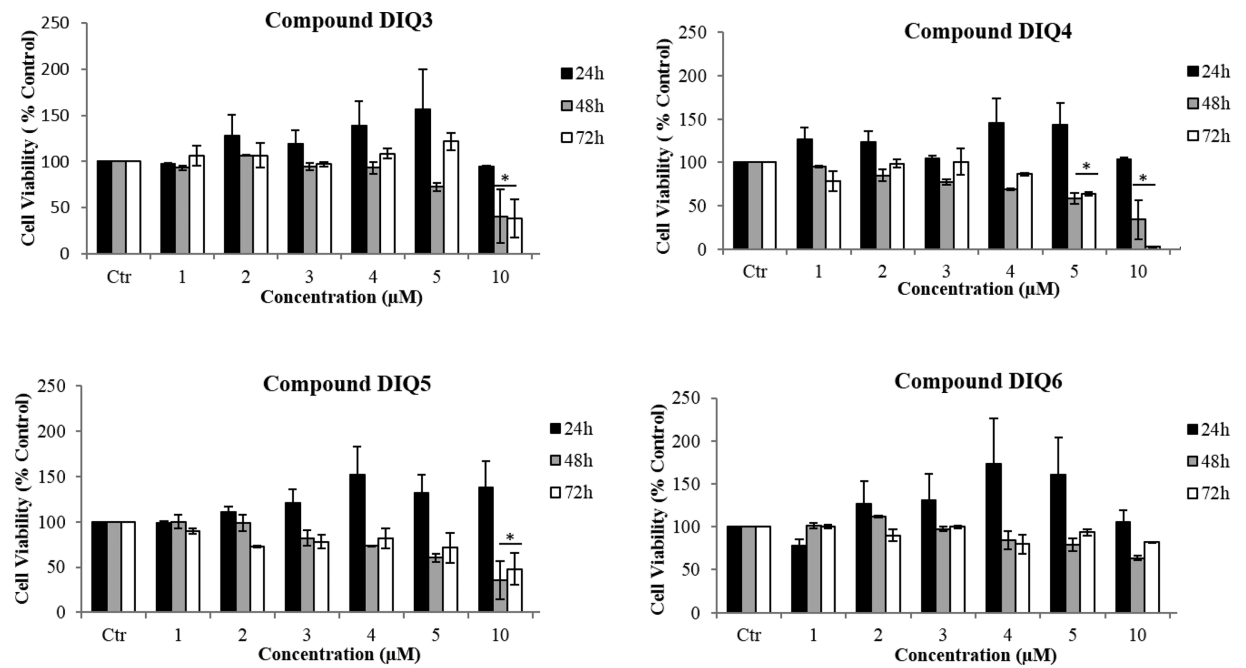

Figure 3. DIQ3 and related derivatives (DIQ4-6) had relatively limited toxicity on the viability of FHs74Int cell line as assessed by MTT for doses up to $5 \mu \mathrm{M}$. Experiment was performed in sextuplicates for each condition. Results are expressed as percent of control. The data are reported as mean of $n=2 \pm \operatorname{SEM}(* P<0.05, * * P<0.01$ using Student's $t$-test $)$.

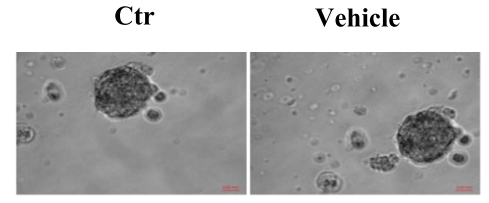

DIQ3

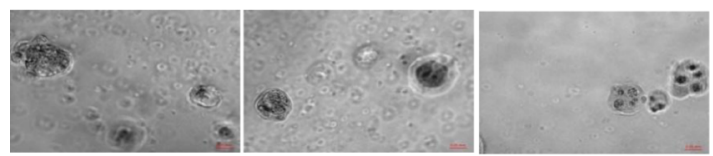

DIQ4

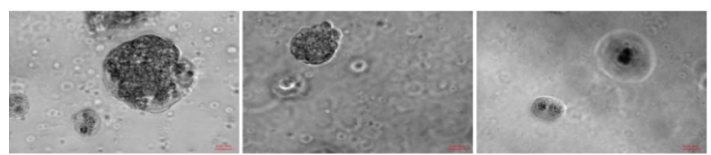

DIQ5

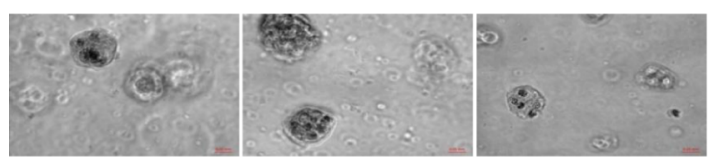

DIQ6

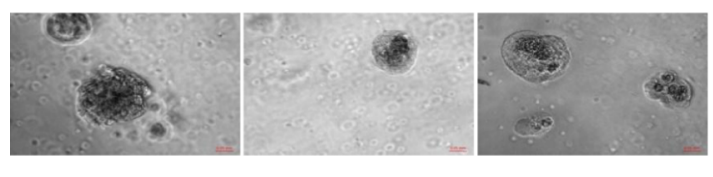

$0.01 \mu \mathrm{M}$

$0.1 \mu \mathrm{M}$

$1 \mu \mathrm{M}$

Figure 4. DIQ3 and related derivatives inhibit size and number of HCT116 colonospheres in generation 1. Effect of DIQ3 and its derivatives on colonospheres using sphere formation assay. Representative bright-field images of HCT116 colon spheres in Matrigel at generation 1/day 11 . HCT116 cells were plated in Matrigel at a density of 2000 cells/well. Images were visualized by Axiovert inverted microscope at $20 \mathrm{X}$ magnification and analyzed by Carl Zeiss Zen 2012 image software.

cancer cells. DIQ3 and its related derivatives inhibited the viability of HCT116 even at pharmacologically achievable micromole concentrations in a time- and dose-dependent manner (Figure 2). Interestingly, a DIQ3 concentration as low

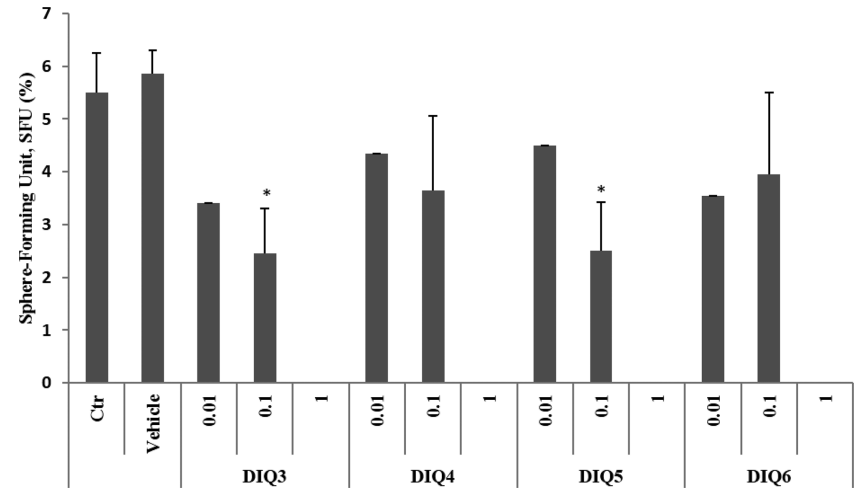

Figure 5. Effect of DIQ3 and its related derivatives (DIQ4-6) on inhibiting the self-renewal ability of the HCT116 colon cancer cells in generation 1. Cells were cultured in Matrigel at a density of 2000 cells/well for 11 days. The generated spheres are referred to as $G_{1}$ (generation 1) spheres. These spheres were treated in duplicates with increasing concentrations of the drugs $(0.01,0.1,1 \mu \mathrm{M})$ or media (Ctr). Media or treatment was replenished every 2 days. Spheres were counted by phase contrast microscopy at day 11 of sphere culture. Results are expressed as SFU which is calculated according to the following formula: $\mathrm{SFU}=$ (number of spheres counted $\times(100) /$ number of input cells). The data were reported as mean of $n=2 \pm$ SEM $(* P<0.05$ using the Student's $t$-test).

as $4 \mu \mathrm{M}$ was able to inhibit cell viability by approximately more than $50 \%$ at $24 \mathrm{~h}$. It is worth noting that the toxicity of varying concentrations $(1-10 \mu \mathrm{M})$ of DIQ3 and related derivatives was investigated in FHs74Int cells derived from normal human fetal intestinal tissue by MTT assay. Interestingly, DIQ3 and related derivatives had relatively limited toxicity when applied at doses up to $5 \mu \mathrm{M}$ and over a $72 \mathrm{~h}$ period (Figure 3 ).

DIQ3 Targets an Enriched Population of Colon Cancer Stem/Progenitor Cells. The ability to grow as nonadherent spheroids has been widely used to assess the selfrenewal capability of CSCs. We investigated colonosphere formation of HCT116 cells, a salient feature of CSCs. To better visualize their sphere-forming capabilities in $3 \mathrm{D}$ cultures, HCT 116 cells were cultured as single cells in Matrigel for 11 days in the presence and absence of compound DIQ3 or its derivatives. The spheres were then visualized under an inverted 


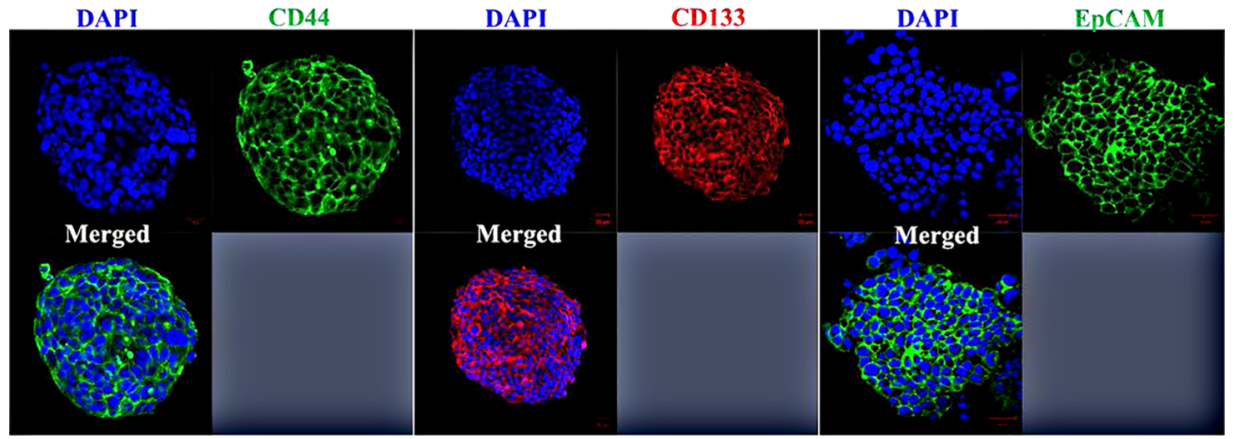

Figure 6. Human HCT116 cells possess a CSC-like population with sphere forming capacity. Representative immunofluorescence imaging of control HCT116 $\mathrm{G}_{1}$ spheres stained for stem cell markers using CD44, CD133, and EpCAM. The nuclei were stained with antifade reagent Fluorogel II with DAPI. Scale bar $20 \mu \mathrm{m}$.

light microscope and bright-field images were taken (Figure 4). Our data showed that HCT116 had a unique population of sphere-forming cells, suggesting the presence of cells with stem cell-like properties. Notably, the sphere-forming unit (SFU) was always lower in drug-treated cells compared with that of the control condition in a dose-dependent manner. Interestingly, the percent of spheres decreased to about $50 \%$ at $0.1 \mu \mathrm{M}$ of DIQ3 and complete inhibition of sphere formation was achieved in wells treated with $1 \mu \mathrm{M}$ of the compounds (Figure 5).

We assessed the presence of stem cell markers in 3-D Matrigel culture within the HCT116 cell populations. Immunofluorescence staining showed high expression of CD44, CD133, and EpCAM in control HCT116 spheres at $\mathrm{G}_{1}$ (Figure 6) indicating enriched stemness in these cells. To understand the mechanism of inhibition of colon sphere formation by DIQ3, we evaluated sphere proliferation by Ki67 expression and DNA apoptotic fragmentation using a Tunel assay (Figure 7). It appeared that the mechanism of inhibition

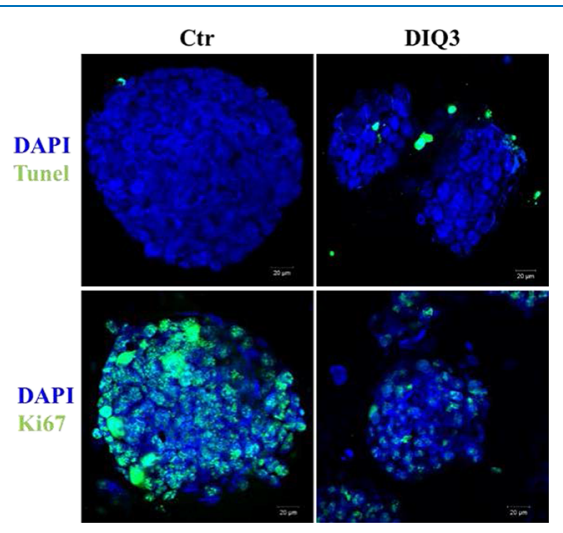

Figure 7. Tunel and Ki67 staining in HCT116 colon $\mathrm{G}_{1}$ spheres. Representative immunofluorescence imaging of control (Ctr) and treated spheres with $0.5 \mu \mathrm{M}$ DIQ3 after Tunel and Ki67 staining. Scale bar $20 \mu \mathrm{m}$.

of colon sphere formation was mainly due to inhibition of proliferation because colon spheres that were formed in the presence of DIQ3 had much lower Ki67 staining and were much smaller in size compared with the control. Treatment with $0.5 \mu \mathrm{M}$ DIQ3 also showed Tunel-positive cells in HCT16 colon spheres as compared to the control (Figure 7).

\section{CONCLUSIONS}

Diminoquinone compounds (DIQ3-6) have been widely investigated as potent anticancer agents. On the basis of the promising anticancer activity of DIQ3, we were interested in studying its antitumor properties in $2 \mathrm{D}$ and $3 \mathrm{D}$ models. To the best of our knowledge, this is the first study to investigate the synthesis of these components and the effect of DIQ3 on colon cancer cells with stem-like properties.

Recent growing evidence suggests that the tumor has a specialized malignant cell population, characterized by selfrenewing, multipotent, and tumor initiating properties, which drives tumor development. This subpopulation is referred to as cancer stem-like cells, which are generated from normal stem or precursor cells within tissues after mutations occur. ${ }^{18}$ Discovery of these CSCs has provided a new insight into carcinogenesis where this highly resistant population can be held accountable for uncontrolled growth, relapse, and metastasis. We evaluated the ability of DIQ3 to target the subpopulation of stem/progenitor cells in HCT116 cells using a 3D sphere formation assay. Remarkably, treatment with DIQ3 at a concentration as low as $0.1 \mu \mathrm{M}$ inhibited significantly the SFU. This suggests that the therapeutic effect of DIQ3 is exerted via targeting the CSCs. Our current findings make DIQ3 and its derivatives somewhat selective, which is the most essential aspect sought after in chemotherapeutic drugs. Thus, this study will provide the basis for proposing DIQ3 as a nontoxic and stable compound for additional testing.

\section{MATERIALS AND METHODS}

General Procedures and Reagents. Melting points were determined using the DigiMelt apparatus and were uncorrected. NMR spectra were determined in deuterated DMSO on a Bruker AM 500 NMR spectrometer. Chemical shifts are reported in $\mathrm{ppm}(\delta)$. Infrared spectra were recorded using Thermo Scientific iD3 ATR for Nicolet iS5 FT-IR spectrometer. The IR bands are reported as wave numbers $\left(\mathrm{cm}^{-1}\right)$. TLC was performed on TLC Silica gel 60 F254 (used directly as received). For high-resolution mass spectra (HRMS), the samples were analyzed by flow-injection analysis on a Thermo Fisher Scientific LTQ Orbitrap (San Jose, CA) operated in the centroid mode. The samples were injected into a mixture of $50 \% \mathrm{MeOH} / \mathrm{H}_{2} \mathrm{O}$ and $0.1 \%$ formic acid at a flow of $0.2 \mathrm{~mL} / \mathrm{min}$. Source parameters were $5.5 \mathrm{kV}$ spray voltage, capillary temperature of $275{ }^{\circ} \mathrm{C}$, and sheath gas setting of 20 . Spectral data were acquired at a resolution of 100000 full 
width at half-maximum with the lock mass feature, which typically results in sufficient mass accuracy.

The starting materials used were commercially available and purchased from standard chemical suppliers.

Synthesis of DIQ3 through Intermediates $3 a, 4 a$ and 5a. (E)-2-(((2-Aminophenyl)imino)methyl)benzonitrile (3a). $o$-Phenylenediamine $(3.05 \mathrm{~g}, 28.2 \mathrm{mmol})$ and $o$-cyanobenzaldehyde (4.55 g, $34.7 \mathrm{mmol}$ ) were dissolved in ethanol (11 $\mathrm{mL}$ ). The reaction was stirred at room temperature for $45 \mathrm{~min}$. Precipitates formed, and the solution was placed in an ice bath. The crystals were then collected by suction filtration and washed with cold ethanol. The desired product was obtained as orange crystals $(5.73 \mathrm{~g}, 92 \%), \mathrm{mp} 99-103{ }^{\circ} \mathrm{C}$.

${ }^{1} \mathrm{H}$ NMR (500 MHz, DMSO-d $): \delta 5.48(\mathrm{~s}, 3 \mathrm{H}), 6.59$ (ddd, $J=8.3,7.2,1.4 \mathrm{~Hz}, 1 \mathrm{H}), 6.75(\mathrm{dd}, J=8.1,1.4 \mathrm{~Hz}, 1 \mathrm{H}), 7.04$ (ddd, $J=8.3,7.1,1.4 \mathrm{~Hz}, 1 \mathrm{H}), 7.31(\mathrm{dd}, J=8.0,1.4 \mathrm{~Hz}, 1 \mathrm{H})$, $7.66(\mathrm{td}, J=7.6,1.3 \mathrm{~Hz}, 1 \mathrm{H}), 7.84(\mathrm{td}, J=7.7,1.3 \mathrm{~Hz}, 1 \mathrm{H})$, $7.98(\mathrm{dd}, J=7.8,1.3 \mathrm{~Hz}, 1 \mathrm{H}), 8.08-8.22(\mathrm{~m}, 1 \mathrm{H}), 8.87(\mathrm{~s}$, $1 \mathrm{H}) ;{ }^{13} \mathrm{C}$ NMR DEPT $135\left(126 \mathrm{MHz}, \mathrm{DMSO}-d_{6}\right): \delta 115.58$, $116.49,117.19,129.61,131.28,131.41,133.92,135.25$, $151.83 ;{ }^{13} \mathrm{C}$ NMR $\left(126 \mathrm{MHz}, \mathrm{CDCl}_{3}\right): \delta 111.38,115.91$, 116.73, 118.13, 118.49, 129.40, 129.49, 130.51, 132.87, 134.24, 134.67, 138.62, 144.01, 151.28; FTIR $\left(\mathrm{cm}^{-1}\right): 3444(\mathrm{w}), 3349$ $(\mathrm{w}), 2216(\mathrm{w}), 1607(\mathrm{~m}), 1488(\mathrm{~m}), 1371(\mathrm{w}), 1311(\mathrm{~m})$, $1262(\mathrm{~m}), 1156(\mathrm{~m}), 753$ (s); HRMS (ESI-Orbitrap) $m / z$ : [M $+\mathrm{H}]^{+}$calcd for $\mathrm{C}_{14} \mathrm{H}_{12} \mathrm{~N}_{3}^{+}$, 222.1026; found, 222.1026.

2-(((2-Aminophenyl)amino)methyl)benzonitrile (4a). 3a (0.81 g, $3.7 \mathrm{mmol})$ was dissolved partially in methanol (30 $\mathrm{mL}$ ), and $\mathrm{NaBH}_{4}$ was added gradually. The solution was orange at first and became lighter over time. At the end of the reaction, the solution was pale yellow. The reaction was done at room temperature, was monitored by TLC, and was complete within $1 \mathrm{~h}$. Water was added to the solution and the product crashed out as a white precipitate. The precipitate was then collected by suction filtration and was washed thoroughly with water. The desired product was obtained as a white solid (0.73 g, 90\%), mp $120-123{ }^{\circ} \mathrm{C}$.

${ }^{1} \mathrm{H}$ NMR (500 MHz, DMSO- $\left.d_{6}\right): \delta 4.47(\mathrm{~d}, J=5.8 \mathrm{~Hz}, 2 \mathrm{H})$, $4.59(\mathrm{~s}, 2 \mathrm{H}), 5.26(\mathrm{t}, J=5.8 \mathrm{~Hz}, 1 \mathrm{H}), 6.25-6.33(\mathrm{~m}, 1 \mathrm{H})$, 6.39-6.47 (m, 2H), 6.54-6.70 (m, 1H), $7.44(\mathrm{td}, J=7.5,1.3$ $\mathrm{Hz}, 1 \mathrm{H}), 7.56(\mathrm{dd}, J=8.0,1.2 \mathrm{~Hz}, 1 \mathrm{H}), 7.65$ (td, $J=7.6,1.3$ $\mathrm{Hz}, 1 \mathrm{H}), 7.83$ (dd, $J=7.7,1.4 \mathrm{~Hz}, 1 \mathrm{H}) ;{ }^{13} \mathrm{C}$ NMR DEPT 135 $\left(126 \mathrm{MHz}, \mathrm{DMSO}-d_{6}\right): \delta 45.88,110.74,114.86,117.94$, $118.11,128.13,128.69,133.36,133.71 ;{ }^{13} \mathrm{C}$ NMR $(126 \mathrm{MHz}$, DMSO- $\left.d_{6}\right): \delta 45.91,110.75,111.07,114.87,117.94,118.00$, $118.12,128.13,128.70,133.36,133.70,135.43,136.04$, 144.52; FTIR $\left(\mathrm{cm}^{-1}\right): 3355(\mathrm{w}), 2224(\mathrm{w}), 1622(\mathrm{w}), 1597$ $(\mathrm{w}), 1506(\mathrm{~m}), 1458(\mathrm{w}), 1273(\mathrm{~m}), 1257(\mathrm{~m}), 1229(\mathrm{w})$, $1142(\mathrm{w}), 763(\mathrm{~m}), 740(\mathrm{~s})$; HRMS (ESI-Orbitrap) $m / z$ : [M $+\mathrm{H}]^{+}$calcd for $\mathrm{C}_{14} \mathrm{H}_{14} \mathrm{~N}_{3}^{+}, 224.1182$; found, 224.1182 .

(E)-2-(((2-((2-Cyanobenzyl)amino)phenyl)imino)methyl)benzonitrile (5a). 4a $(0.32 \mathrm{~g}, 1.43 \mathrm{mmol})$ and 2cyanobenzaldehyde $(0.23 \mathrm{~g}, 1.75 \mathrm{mmol})$ were dissolved in DMSO (5 mL) and glacial acetic acid (4 drops) was added. The reaction was kept at room temperature and orange needlelike crystals precipitated from the solution, which were collected by suction filtration and washed with methanol to afford the product $(0.44 \mathrm{~g}, 91 \%), \mathrm{mp} 156-160{ }^{\circ} \mathrm{C}$.

${ }^{1} \mathrm{H}$ NMR $\left(500 \mathrm{MHz}, \mathrm{DMSO}-d_{6}\right): \delta 4.62(\mathrm{~d}, J=6.4 \mathrm{~Hz}, 2 \mathrm{H})$, $6.46(\mathrm{t}, J=6.4 \mathrm{~Hz}, 1 \mathrm{H}), 6.57(\mathrm{~d}, J=8.1 \mathrm{~Hz}, 1 \mathrm{H}), 6.66(\mathrm{t}, J=$ $7.5 \mathrm{~Hz}, 1 \mathrm{H}), 7.04-7.14(\mathrm{~m}, 1 \mathrm{H}), 7.36(\mathrm{dd}, J=8.0,1.4 \mathrm{~Hz}$, $1 \mathrm{H}), 7.43(\mathrm{t}, J=7.6 \mathrm{~Hz}, 1 \mathrm{H}), 7.54(\mathrm{~d}, J=7.9 \mathrm{~Hz}, 1 \mathrm{H}), 7.64$ $(\mathrm{td}, J=7.7,1.3 \mathrm{~Hz}, 1 \mathrm{H}), 7.68(\mathrm{t}, J=7.6 \mathrm{~Hz}, 1 \mathrm{H}), 7.82(\mathrm{~d}, J=$
$7.7 \mathrm{~Hz}, 1 \mathrm{H}), 7.85(\mathrm{t}, J=7.4 \mathrm{~Hz}, 1 \mathrm{H}), 7.97(\mathrm{~d}, J=7.7 \mathrm{~Hz}, 1 \mathrm{H})$, $8.24(\mathrm{~d}, J=7.8 \mathrm{~Hz}, 1 \mathrm{H}), 8.91(\mathrm{~s}, 1 \mathrm{H}) ;{ }^{13} \mathrm{C}$ NMR DEPT 135 $\left(126 \mathrm{MHz}, \mathrm{DMSO}-d_{6}\right): \delta 45.27,111.11,117.02,117.16$, $128.27,128.43,129.83,131.07,131.64,133.50,133.84,133.94$, 135.00, 152.93; ${ }^{13} \mathrm{C}$ NMR (126 MHz, DMSO-d $\left.d_{6}\right): \delta 45.27$, $110.20,110.91,111.12$, 117.02, 117.16, 117.96, 119.32, 128.27, $128.43,129.83,131.07,131.64,133.50,133.84,133.94,134.63$, $135.00,138.51,144.09,144.33,152.93$; FTIR $\left(\mathrm{cm}^{-1}\right): 3388$ (m), $2210(\mathrm{w}), 1595(\mathrm{~m}), 1508(\mathrm{~m}), 1488(\mathrm{w}), 1453(\mathrm{w})$, $1423(\mathrm{w}), 1361(\mathrm{w}), 1327(\mathrm{~m}), 1293(\mathrm{~m}), 1271(\mathrm{~m}), 1160$ (m), 1043 (w), 763 (s), 738 (s); HRMS (ESI-Orbitrap) $\mathrm{m} / z$ : $[\mathrm{M}+\mathrm{H}]^{+}$calcd for $\mathrm{C}_{22} \mathrm{H}_{17} \mathrm{~N}_{4}^{+}, 337.1448$; found, 337.1448.

2-((5-Iminoisoquinolino[3,4-b] quinoxalin-7(5H)-yl)methyl)benzonitrile (DIQ3). 5a (0.065 g, $0.20 \mathrm{mmol}$ ) was dissolved partially in acetonitrile $(5 \mathrm{~mL})$ and excess of $\mathrm{KCN}$, was dissolved previously in minimal water, and was added to the solution and left for $24 \mathrm{~h}$. The product was collected by suction filtration and washed with cold methanol to yield orange crystals $(0.060 \mathrm{~g}, 86 \%)$. The product decomposed at $212-215^{\circ} \mathrm{C}$.

${ }^{1} \mathrm{H}$ NMR (500 MHz, DMSO-d $): \delta 5.99(\mathrm{~s}, 2 \mathrm{H}), 7.17$ (d, $J$ $=7.9 \mathrm{~Hz}, 1 \mathrm{H}), 7.44-7.51(\mathrm{~m}, 3 \mathrm{H}), 7.55(\mathrm{td}, J=7.7,1.4 \mathrm{~Hz}$, $1 \mathrm{H}), 7.62(\mathrm{ddd}, J=8.5,7.1,1.6 \mathrm{~Hz}, 1 \mathrm{H}), 7.77(\mathrm{td}, J=7.4,1.6$ $\mathrm{Hz}, 1 \mathrm{H}), 7.81(\mathrm{td}, 1 \mathrm{H}), 7.95(\mathrm{dd}, J=7.6,1.4 \mathrm{~Hz}, 1 \mathrm{H}), 7.99$ (dd, $J=7.9,1.5 \mathrm{~Hz}, 1 \mathrm{H}), 8.40(\mathrm{dd}, J=7.6,1.6 \mathrm{~Hz}, 1 \mathrm{H}), 8.61$ (dd, $J=7.6,1.6 \mathrm{~Hz}, 1 \mathrm{H}), 8.65(\mathrm{~s}, 1 \mathrm{H}) ;{ }^{13} \mathrm{C}$ NMR DEPT 135 $\left(126 \mathrm{MHz}, \mathrm{DMSO}-d_{6}\right): \delta 45.50,115.69,124.20,124.86$, $126.90,127.34,128.61,130.45,131.52,132.06,132.35,133.94$, 134.16; ${ }^{13} \mathrm{C}$ NMR (126 MHz, DMSO- $\left.d_{6}\right): \delta 45.50,110.99$, $115.69,117.79,124.21,124.87,126.91,127.34,128.62,130.45$, $131.38,131.53,131.96,132.07,132.36,132.42,133.94,134.16$, $134.55,139.54,143.91,144.66,160.41$; FTIR $\left(\mathrm{cm}^{-1}\right): 3260$ (w), $2231(\mathrm{w}), 1570(\mathrm{w}), 1538(\mathrm{~m}), 1526(\mathrm{~s}), 1477(\mathrm{w}), 1466$ $(\mathrm{w}), 1445(\mathrm{w}), 1389(\mathrm{~m}), 1359(\mathrm{~m}), 1342(\mathrm{w}), 1306(\mathrm{~m})$, $1184(\mathrm{w}), 1057(\mathrm{w}), 893(\mathrm{~m}), 781(\mathrm{~m}), 754(\mathrm{~m}), 741(\mathrm{~s})$; HRMS (ESI-Orbitrap) $m / z:[\mathrm{M}+\mathrm{H}]^{+}$calcd for $\mathrm{C}_{23} \mathrm{H}_{16} \mathrm{~N}_{5}{ }^{+}$, 362.1400; found, 362.1403 .

The different analogs of DIQ were synthesized in a similar manner (see Supporting Information).

Cell Culture and Treatment. HCT116 cell lines (ATCC, USA) were cultured and maintained in RPMI 1640 (SigmaAldrich, UK) with $20 \mathrm{mM}$ HEPES and L-glutamine. Cells were maintained in an incubator at $37{ }^{\circ} \mathrm{C}$ in a humidified atmosphere of $5 \% \mathrm{CO}_{2}$ and $95 \%$ air. Cell culture media was supplemented with antibiotics [1\% penicillin-streptomycin $(100 \mathrm{U} / \mathrm{mL})], 10 \%$ heat-inactivated fetal bovine serum (FBS) (Sigma-Aldrich, Germany), and $5 \mu \mathrm{g} / \mathrm{mL}$ Plasmocin prophylactic (InvivoGen). FHs74Int, normal human fetal intestinal cell line, was grown in Dulbecco's modified Eagle's medium with $10 \% \mathrm{FBS}$ at $37{ }^{\circ} \mathrm{C}$ under $5 \% \mathrm{CO}_{2}$. Cells were incubated at $37{ }^{\circ} \mathrm{C}$ in a humidified incubator containing $5 \% \mathrm{CO}_{2}$. Stocks of the compounds DIQ3-6 were prepared by dissolving $5 \mathrm{mg}$ in 1 $\mathrm{mL}$ of DMSO. Dilutions were prepared such that the percentage of DMSO on cells was less than $0.1 \%$.

MTT Assay. The effects of compounds DIQ3-6 on cell viability was measured in vitro using the MTT ([3-(4,5dimethylthiazol-2-yl)-2,5-diphenyltetrazolium bromide]) assay. Colon cancer and normal FHs74Int cells were plated in 96well culture plates at $5 \times 10^{3}$ cells/well and incubated overnight and then treated in sextuplicates with $0.1 \%$ DMSO or different concentrations of compounds DIQ3-6 for 24, 48, or $72 \mathrm{~h}$. For each time point, $10 \mu \mathrm{L}$ of $5 \mathrm{mg} / \mathrm{mL}$ (in $1 \times \mathrm{PBS}$ ) MTT reagent was added to each well and incubated at $37^{\circ} \mathrm{C}$ 
for $4 \mathrm{~h}$, after which $100 \mu \mathrm{L}$ of solubilizing solution was added. After overnight incubation, the reduced MTT optical density was measured at a wavelength of $595 \mathrm{~nm}$ using an ELISA reader (Multiskan Ex). The percentage of viable cells was determined for each drug concentration with respect to untreated cells and is represented as mean \pm standard error of the mean (SEM).

3D Culture and Sphere-Formation Assay. This assay was performed according to the protocol previously described. ${ }^{19-21} 2000$ cells/well were suspended in cold Matrigel/serum-free medium (1:1) in a total volume of 50 $\mu \mathrm{L}$. HCT 116 cells were seeded uniformly in a circular manner around the bottom rim of the well and allowed to solidify in the incubator at $37{ }^{\circ} \mathrm{C}$ for $1 \mathrm{~h}$. Subsequently, $0.5 \mathrm{~mL}$ of lowserum media treated with compounds DIQ3-6 or DMSO was added gently in the middle of each well. Spheres were replenished with warm media as in the original seeding every other day. Spheres were counted after 10-13 days. To propagate spheres, the medium was aspirated and Matrigel was digested with $0.5 \mathrm{~mL}$ of $1 \mathrm{mg} / \mathrm{mL}$ dispase solution (Invitrogen, Carlsbad, CA), dissolved in serum-free medium for $60 \mathrm{~min}$ at $37{ }^{\circ} \mathrm{C}$. Spheres were then collected and incubated in $1 \mathrm{~mL}$ warm trypsin/EDTA at $37{ }^{\circ} \mathrm{C}$ for $5 \mathrm{~min}$ and then passed through a 20,25, and 27-gauge syringes three times. Cells were counted using a hemocytometer and re-seeded as described above. The sphere-formation unit (SFU) was calculated for each generation as follows: $\mathrm{SFU}=$ (number of spheres formed/number of cells plated $\times 100$. Results were represented as a percentage of the SFU of the treated spheres compared with the untreated ones. Zeiss Axiovert microscope was used for the acquisition of bright field images.

Tunel Assay. Spheres were collected between days 10 and 13 and fixed for $15 \mathrm{~min}$ at $15-25^{\circ} \mathrm{C}$. Spheres were incubated overnight in $70 \%$ ethanol at $4{ }^{\circ} \mathrm{C}$. The next day, spheres were washed with PBS and then incubated in $50 \mu \mathrm{L} /$ condition Tunel reaction mixture for $60 \mathrm{~min}$ at room temperature. After embedding the stained spheres with antifade, a Carl Zeiss LSM 710 laser scanning confocal microscope was used for immunofluorescence analysis.

Immunofluorescence Staining. Collected spheres were immunostained with primary mouse monoclonal anti-Ki67 (1/ 150 dilution) antibody (Santa Cruz Biotechnology, CA) and secondary Alexa 488 goat anti-mouse (Invitrogen, CA) antibody. Spheres were mounted with the anti-fade Fluorogel II with Dapi. Confocal microscopic analyses were performed using a Carl Zeiss LSM 710 laser scanning confocal microscope and images were acquired and analyzed using the Carl Zeiss ZEN 2012 image software.

Statistical Analysis. Data were analyzed using the Student's $t$-test. $P$-values of $p<0.05(*)$ and $p<0.01$ (**) were considered significant and highly significant, respectively. Results are presented as the mean \pm standard error (SEM).

\section{ASSOCIATED CONTENT}

\section{S Supporting Information}

The Supporting Information is available free of charge on the ACS Publications website at DOI: 10.1021/acsomega.8b02698.

Additional figures illustrating ${ }^{1} \mathrm{H}$ NMR, ${ }^{13} \mathrm{C}$ NMR, FTIR, and HRMS spectra, in addition to experimental procedures of all the above mentioned compounds and intermediates (PDF)

\section{AUTHOR INFORMATION}

\section{Corresponding Author}

*E-mail: amro@aub.edu.lb. Phone: (+961)-1-350000, ext. 3894. Fax: 961-1-744464 (H.G.-M.).

ORCID

Jie S. Zhu: 0000-0003-3009-4135

Mark J. Kurth: 0000-0001-8496-6125

Hala Gali-Muhtasib: 0000-0001-6840-3015

Author Contributions

"A.M. and N.J. contributed equally.

Notes

The authors declare no competing financial interest.

\section{ACKNOWLEDGMENTS}

We would like to thank staff of the core facilities in the DTS Building at the American University of Beirut for their help and support. The chemistry part of this article was supported by the National Institutes of Health (DK072517 and DK067003) and royalties from the Beirut Reaction. J.S.Z. is supported by the UC Davis Tara K. Telford CF Fund, UC Davis Dissertation Year Fellowship, and R. Bryan Miller Graduate Fellowship.

\section{REFERENCES}

(1) Gu, Z.; Li, Y.; Ma, S.; Li, S.; Zhou, G.; Ding, S.; Zhang, J.; Wang, S.; Zhou, C. Synthesis, cytotoxic evaluation and DNA binding study of 9-fluoro-6H-Indolo[2,3-b] quinoxaline derivatives. RSC Adv. 2017, 7, 41869-41879.

(2) DeVita, V. T.; Chu, E. A History of cancer chemotherapy. Cancer Res. 2008, 68, 8643-8653.

(3) Avendaño, C.; Menéndez, J. C. Medicinal Chemistry of Anticancer Drugs: Introduction; Elsevier Science, 2008.

(4) Butler, M. S. The role of natural product chemistry in drug discovery. J. Nat. Prod. 2004, 67, 2141-2153.

(5) Kharwar, R. N.; Mishra, A.; Gond, S. K.; Stierle, A.; Stierle, D. Anticancer compounds derived from fungal endophytes: Their importance and future challenges. Nat. Prod. Rep. 2011, 28, 12081228.

(6) Pullman, B. A few considerations on quinones as antitumor agents. Int. J. Quantum Chem. 2009, 30, 95-105.

(7) Malik, E. M.; Müller, C. E. Anthraquinones as pharmacological tools and drugs. Med. Res. Rev. 2016, 36, 705-748.

(8) Guin, P. S.; Das, S.; Mandal, P. C. Electrochemical reduction of quinones in different media: A review. Int. J. Electrochem. 2011, 2011, $1-22$.

(9) Bachur, N. R.; Gordon, S. L.; Gee, M. V.; Kon, H. NADPH cytochrome P-450 reductase activation of quinone anticancer agents to free radicals. Proc. Natl. Acad. Sci. U.S.A. 1979, 76, 954-957.

(10) Obach, R. S.; Kalgutkar, A. S. Reactive electrophiles and metabolic activation. In Comprehensive Toxicol; McQueen, C. A., Ed.; Academic Press: Oxford, 2010; Vol. 1, pp 309-347.

(11) Zissimou, G. A.; Kourtellaris, A.; Manoli, M.; Koutentis, P. A. Redox active quinoidal 1,2,4-benzotriazines. J. Org. Chem. 2018, 83, 9391-9402.

(12) Keane, L.-A.; Mirallai, S.; Sweeney, M.; Carty, M.; Zissimou, G.; Berezin, A.; Koutentis, P.; Aldabbagh, F. Anti-cancer activity of phenyl and pyrid-2-yl 1,3-substituted benzo[1,2,4]triazin-7-ones and stable free radical precursor. Molecules 2018, 23, 574.

(13) Demain, A. L.; Vaishnav, P. Natural products for cancer chemotherapy. Microbiol. Biotechnol. 2010, 4, 687-699.

(14) Wu, C.-P.; Hsieh, C.-H.; Wu, Y.-S. The emergence of drug transporter-Mediated multidrug resistance to cancer chemotherapy. Mol. Pharmaceutics 2011, 8, 1996-2011.

(15) Ke, X.; Shen, L. Molecular targeted therapy of cancer: The progress and future prospect. Front. Lab. Med. 2017, 1, 69-75. 
(16) Babashah, S. Cancer Stem Cells: Emerging Concepts and Future Perspectives in Translational Oncology, 1st ed.; Springer International: Switzerland, 2015.

(17) Bagdasarian, A. L.; Nguyen, H. H.; Palazzo, T. A.; Fettinger, J. C.; Haddadin, M. J.; Kurth, M. J. One-Pot Synthesis of Benzo[4,5]imidazo[2,1-a]isoquinolines and Isoquinolino[3,4b]quinoxalines via Tandem Cyclization Strategies. J. Org. Chem. 2016, 81, 3924-3928.

(18) Aguilar-Gallardo, C.; Simón, C. Cells, stem cells, and cancer stem cells. Semin. Reprod. Med. 2013, 31, 005-013.

(19) Mouhieddine, T. H.; Nokkari, A.; Itani, M. M.; Chamaa, F.; Bahmad, H.; Monzer, A.; El-Merahbi, R.; Daoud, G.; Eid, A.; Kobeissy, F. H.; Abou-Kheir, W. Metformin and ara-a effectively suppress brain cancer by targeting cancer stem/progenitor cells. Front. Neurosci. 2015, 9, 442.

(20) El-Merahbi, R.; Liu, Y.-N.; Eid, A.; Daoud, G.; Hosry, L.; Monzer, A.; Mouhieddine, T. H.; Hamade, A.; Najjar, F.; Abou-Kheir, W. Berberislibanoticaehrenb extract shows anti-neoplastic effects on prostate cancer stem/progenitor cells. PLoS One 2014, 9, No. e112453.

(21) Abou-Kheir, W.; Hynes, P. G.; Martin, P.; Yin, J. J.; Liu, Y.-N.; Seng, V.; Lake, R.; Spurrier, J.; Kelly, K. Self-Renewing Pten-/TP53-/- protospheres produce metastatic adenocarcinoma cell lines with multipotent progenitor activity. PLoS One 2011, 6, No. e26112. 